\title{
GLUCOSE-6-PHOSPHATE DEHYDROGENASE DEFICIENCY
}

\section{IN PROJECT HEAD START CHILDREN}

\author{
Sally Kelly, Ph.D., M.D. \\ Rydia Almy, B.A.
}

OPPORTUNITY to identify the gene defect, glucose-6-phosphate dehydrogenase deficiency, in a high-risk group was offered by Negro children receiving medical examinations in Project Head Start groups in Albany, N.Y., during the summer of 1965 . The screening was undertaken as a pilot project to determine the feasibility of sampling selected populations for inherited biochemical defects. The potential for drug-induced hemolytic anemias and favism was selected for screening because knowledge of the enzyme defect may be helpful in preventing hemolytic crises and in genetic counseling.

Hemolytic crises may be induced in persons with glucose-6-phosphate dehydrogenase deficiency $(1,2)$ by $(a)$ drugs, including primaquine and similar antimalarials, sulfonamides, phenacetin, acetanilid, chloramphenicol, furadantin, isoniazid, antipyrine, probenecid, paraamino salicylate, and acetyl salicylic acid; $(b)$ by diseases, for example, neonatal jaundice (non-isoimmunological), bacterial infections, diabetes, viral infections of the upper respiratory tract, hepatitis, and nephritis; and (c) by other factors, such as fava beans and mothballs.

\section{Method}

Administrative lines were crossed easily in screening children in this locally organized, federally supported Project Head Start. The Albany Board of Education arranged the sampling as part of the medical examinations. Accordingly slips requesting parents' permission to give the children physical examinations in-

Dr. Kelly is associate research scientist (medical genetics) and Miss Almy is a bacteriologist with the division of laboratories and research, New York State Department of Health, Albany. cluded requests for a "hereditary anemia" test. Capillary blood was collected from a group of children at the end of the medical examinations in one community group and as a special event in two others. A list of children in whom the deficiency was detected by the screening was returned to the board of education, and individual laboratory reports of the deficiency with an offer to perform a confirmatory test were sent to the family or to clinic physicians named by the parents. The Head Start nurse or administrator visited the children's homes to inform the parents of the potentiality for drug-induced anemia in their children and to urge them to seek medical advice.

The deficiency in glucose-6-phosphate dehydrogenase was demonstrated by Oski and Growney's histochemical method of methylene blue oxidation-reduction by red cells (3). Their interpretation follows: Enzyme-deficient cells in the presence of glucose fail to reduce leucomethylene blue (colorless form of dye); however, red cells normally slowly reduce leucomethylene blue which then enters the red cell where it is reoxidized to the blue form of the dye. An average of 10 percent (7.8-16.9) of normal cells are stained blue. In preparations made from persons with the enzyme defect, less than 0.2 percent of cells stain.

Capillary blood from 52 girls and 83 boys (age 4-5 years) attending Project Head Start was collected in 1 to 3 heparinized hematocrit tubes and stored overnight at $5-10^{\circ} \mathrm{C}$. in $2: 1$ Alsever's medium. The red cells were sedimented by centrifugation, combined with equal volumes of substrate-dye mixture, and incubated $3-4$ hours at $37^{\circ} \mathrm{C}$. They were considered enzyme deficient if, under microscopic observation at $120 \times$, they remained colorless 


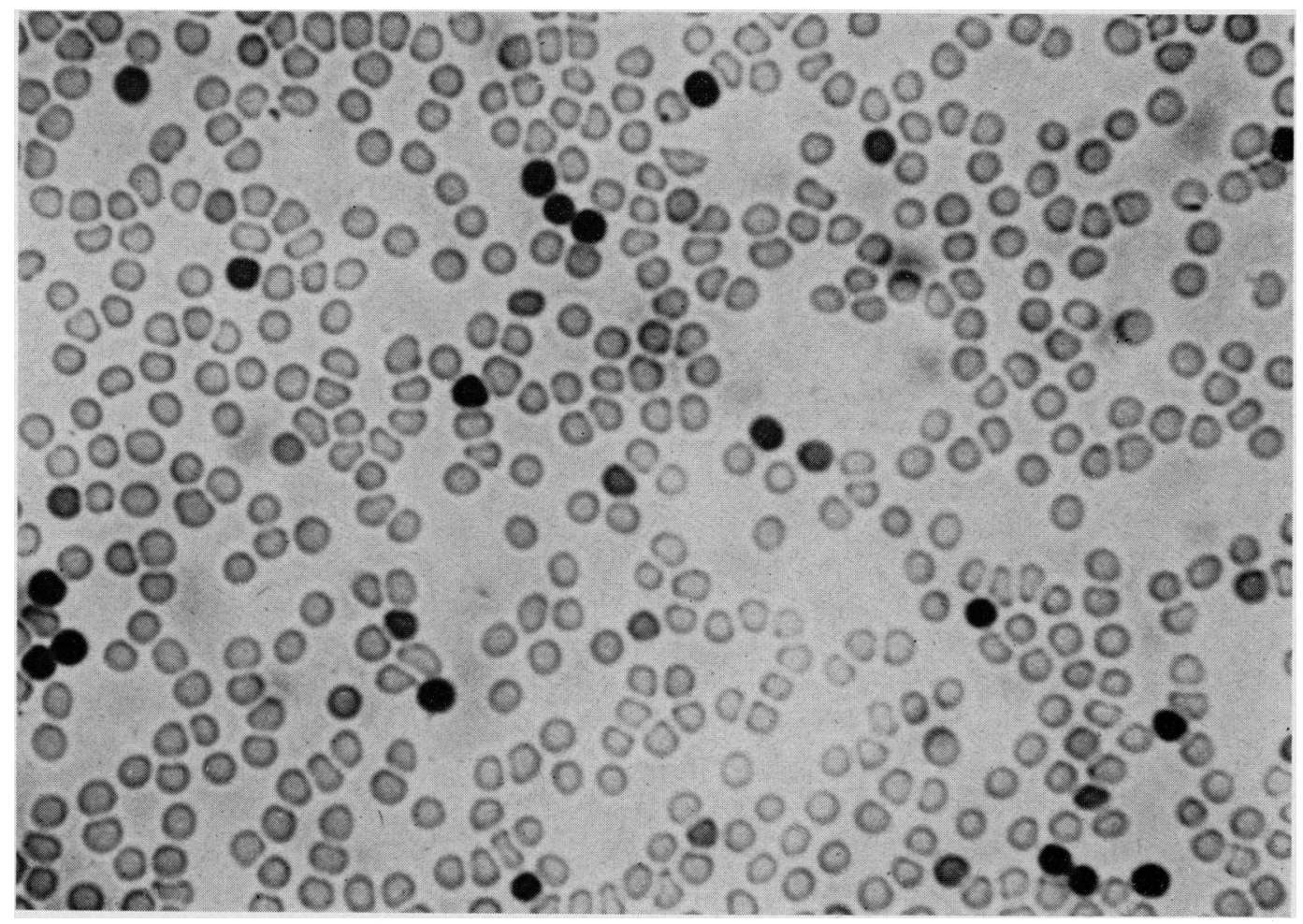

\section{Methylene blue stained red cells from control sample (420x). Red cells in enzyme-deficient samples do not stain.}

or if only a few cells stained faintly. Comparable samples from four normal white adults included in the assays contained from 6-10 percent of colored cells (see illustration). Samples which were colorless were assayed a second time, 24 hours or more later, because preliminary experiments with the controls indicated that more cells were stained when the samples were equilibrated overnight in the storage medium.

\section{Results}

Cells of 15 samples did not stain in the first assay. In duplicate assays on a later date, those from nine remained colorless and the samples were considered enzyme deficient. Three samples with cells that stained in the second assay were considered normal. Three other samples were insufficient for use in the second test.

Enzyme-deficient red cells were found in the samples from four girls and five boys, giving an incidence in this small population of 7.7 percent in girls and 6.0 percent in boys.
A quantitative assay should be the initial step in followup to confirm the result of the screening and to identify the genotype. Satisfactory followup was not achieved in this Head Start group. The family physician of two children requested information on drug susceptibilities. The agency physician of another, a State ward, referred the child and his foster parents to an associated genetics counseling unit. Five children claimed to receive medical attention at hospital clinics rather than from family physicians, although in at least two cases no records were found. Our efforts were thwarted by the temporary residence of the population and the failure of many families to maintain contact with a physician.

\section{Discussion}

The frequency of the enzyme defect in the boys of this small group approximates that of the associated clinical abnormality in the American Negro (4). While the screening did not distinguish genotypes, it was a first step in 
identifying families with the gene defect. Its clinical value is not entirely predictable from the screening because hemolytic anemia and the enzyme defect are sometimes dissociated $(\mathbb{2}-6)$.

Significance of the assay in samples from heterozygous girls is questionable because the test is qualitative (3). Girls were included in the screening, however, because initial use of the assay apparently was limited to samples from males, and it was hoped that suggestions of deficiency in the screening might be verified by a quantitative test. The frequency of hemolytic anemia recently reported in enzymedeficient females (2) supports their inclusion in screenings for the defect.

Sampling and testing a high-risk population for the enzyme defect, glucose-6-phosphate dehydrogenase deficiency, are technically feasible, as demonstrated here. Practicality of such a screening is limited, however, by the inability to transfer the information to a useful record. Burdening the family with the fact may not be helpful because most of the drugs involved are available by prescription only, and the disease is chiefly a potential one. The population at risk lends itself poorly to followup through a family physician, and there is no repository or active register for storing the information. Before large-scale screening for this kind of defect is undertaken, a reasonable program for followup is needed.

\section{Summary}

Children attending Project Head Start were screened for glucose-6-phosphate dehydrogenase deficiency by Oski and Growney's histochemical method. The incidence of the defect in the 135 Negro boys and girls tested was approximately 7 percent. Genotypes were not distinguishable. Followup was attempted by transferring the information to family physicians, the families, or to clinic records when available.

\section{REFERENCES}

(1) Stanbury, J. B., Wyngaarden, J. B., and Fredrickson, D. S.: The metabolic basis of inherited disease. Ed. 2. McGraw-Hill, Inc., New York, 1966, p. 1434.

(2) Burka, E. R., Weaver, Z. III, and Marks, P. A.: Clinical spectrum of hemolytic anemia associated with glucose-6-phosphate dehydrogenase deficiency. Ann Intern Med 64: 817-825 (1966).

(3) Oski, F. A., and Growney, P. M.: A simple micromethod for the detection of erythrocyte glucose6-phosphate dehydrogenase deficiency. J Pediat 66 : 90-93 (1965).

(4) Beutler, E.: The hemolytic effect of primaquine and related compounds: A review. Blood 14: 103-139 (1959).

(5) Childs, B., et al.: A genetic study of a defect in glutathione metabolism of the erythrocyte. Bull Johns Hopkins Hosp 102 : 21-37 (1958).

(6) Alving, A. S., et al.: Biochemical and genetic aspects of primaquine-sensitive hemolytic anemia. Ann Intern Med 49: 240-248 (1958).

\section{Migrant Family Health Services}

Grants totaling $\$ 3,265,810$ to 73 projects for migrant family health services in 23 States have been awarded by the Public Health Service. Authorized by the Migrant Health Act, the grants will be used to improve health services for domestic migratory farmworkers and their families.

Services covered by the grants include family health service clinics, medical and dental care, nursing services, sanitation services, and health education. In some projects, funds will be used to train selected migrant workers to serve as health aides.

State or local public agencies and nonprofit private organizations are eligible for migrant health grants. Grantee institutions must pay part of the project cost. 